\title{
Evaluation of antiepileptic activity of methanolic leaves extract of Tragia involucrata Linn. in mice
}

\author{
Ganapathi G. Varma ${ }^{1}$, Benson K. Mathai ${ }^{1}$, Kuntal Das ${ }^{2, \star}$, Girish Gowda ${ }^{1}$, \\ S. Rammohan ${ }^{1}$, John Wilking Einstein ${ }^{1}$ \\ ${ }^{1}$ Department of Pharmacology and Toxicology, St. John's Pharmacy College, \\ \#6, II Main, R.P.C Lay out, Bangalore, Karnataka, India \\ 2 Department of Pharmacognosy and Phytochemistry, Krupanidhi College of Pharmacy, \\ \#12/1, Carmelaram Post, Varthur Hobli, Bangalore, Karnataka, India \\ *Phone: +919632542846 \\ *E-mail address: drkkdsd@gmail.com
}

\begin{abstract}
The present investigation was aimed to study an antiepileptic activity of methanolic extract of Tragia involucrata Linn in mice. In vivo screening models like maximal electroshock-induced convulsion (MES), pentylenetetrazole (PTZ) and picrotoxin (PTX) induced models are used to evaluate the antiepileptic effects of the extracts. The biochemical estimation was done by measuring the lipid peroxidation and reduced glutathione (GSH). In the MES induced convulsion, methanolic extract of Tragia involucrata (METI) at high dose $(800 \mathrm{mg} / \mathrm{kg}$ body weight), showed high significant inhibition on tonic hind limb extension (THLE, $6.83 \pm 0.30^{* * *}$ ) and decrease in duration of stupor period $\left(108.7 \pm 6.53^{* * *}\right)$. In PTZ and PTX induced model METI $(400 \mathrm{mg} / \mathrm{kg}$ and $800 \mathrm{mg} / \mathrm{kg})$ showed significant delay on the onset of convulsions, decreased duration of convulsion and reduced mortality significantly. It also showed significant decrease in brain MDA level in lipid peroxidation profile, and increase in the brain glutathione levels in mice against PTZ induced convulsion. The results confirmed that Tragia involucrata Linn possesses dose dependent antiepileptic activity.
\end{abstract}

Keywords: Anticonvulsant activity; Tragia involucrate; Pentylenetetrazole; Picrotoxin; Maximal electroshock

\section{INTRODUCTION}

Mental, behavioral, and social health problems are an increasing part of the health problems the world over. The World Health Organization (WHO) has declared 2001 as the year for mental health in recognition of the burden that mental and brain disorders pose on people and families affected by them (Medappa, 2001). In the last ten years of the 20th century is called in neuroscience "decade of the brain". Epilepsy usually begins in childhood, potentially impeding education, employment, social relationships and development of a sense of self-worth. Epilepsy is among the disorders that are strongly associated with significant psychological and social consequences for everyday living. There is no doubt that epilepsy belongs to the most encountered neurological conditions since the disease affects approximately $1 \%$ of the population. Epilepsy is one of the most common neurological disorders with reported prevalence of $6-8 / 100,000$, incidence of $30-50 / 100,000$ per year and 
cumulative incidence of $3 \%$. It requires prolonged and sometimes life-long drug therapy (Rout and Kar, 2010). The prevalence of epilepsy in developing countries is usually higher than in developed countries (Mac et al., 2007). However, the problem of adverse effects has also not been circumvented completely and approximately $30 \%$ of the patients continue to have seizures with current Antiepileptic drugs therapy (Ezekiel et al., 2010). Hence, search should continue to develop newer, more effective, and safer neuroprotective agents for treatment of epilepsy. Medicinal plants used in traditional medicine for the treatment of epilepsy have been scientifically shown to posses promising anticonvulsant activities in animal models for screening for anticonvulsant activity (Wannang et al., 2008).

Herbal medicine is still the mainstay of about $75-80 \%$ of the world population, mainly in the developing countries, for primary health care because of better cultural acceptability, better compatibility with the human body and lesser side effects. Global estimates indicate that $80 \%$ of about 4 billion population cannot afford the products of the Western Pharmaceutical Industry and have to rely upon the use of traditional medicines which are mainly derived from plant material (Joy et al., 2001). Considering the great reliance on traditional medicinal plants for treatment of diseases and the potential for drug discovery; it becomes relevant to search for potent, effective and relatively safe plant medicines.

Of late Tragia involucrata is a traditional medicinal plant, widely disturbed throughout India from Punjab and Lower Himalayas eastwards to Assam and Meghalaya, ascending upto an altitude of $750 \mathrm{~m}$ and southwards to Kerala. The major chemical constituents of the plant are flavonoides, phenolics, tannins (Samy et al., 2006) and alkaloids (Palani et al., 2009). In traditional medicinal system, different parts of the plant have been mentioned to be useful in a variety of diseases. The decoction of the leaves is being used for the treatment of skin infection, pain, swelling, children scabies and eczema. The roots have been reported to possess diaphoretic and alternative actions and are given when the extremities like cold during fever, for pains in legs and arms. A decoction of the root is found to be useful in relieving bronchitis and the attendant fever (Kirtikar and Basu, 1977), skin eruptions, venereal diseases, blood purification (Samy et al., 1998; Sarada et al., 2002). Tragia involucrata is one of the major constituent of all the antidiabetic formulations available in the market (Kar et al., 2003). The plant is been used predominantly to treat asthma in many traditional medicines decoction, 10-40 ml taken twice a day by mouth (Savithramma et al., 2007). In baldness (fruit); as a tonic, antileprotic (root). Used for treating, diarrhoea, excessive urination, vomiting, dermatosis, and itching of the skin (Udayan et al., 2008), paste made from the roots of this plant was applied externally on forehead for three days to treat migraine (Udayan et al., 2008) and is taken internaly to treat piles (Silja et al., 2008). Decoction of leaves is taken with the leaves of Cipadessa baccifera Miq and Aristolochia talaga to cure scorpion, insect and snake bites (Ayyanar and Ignacimuthu, 2005). Juice from crushed roots of Tragia involucrata is taken to cure Tumor, elephantiasis (Rahmatullah et al., 2010). Recent activities like Psychopharmacological activity (Dhara et al., 2002), Nephroprotective activity, wound healing activity, Anti inflammatory activity, Analgesic activity (Dhara et al., 2000), Hypoglycemic activity (Kar et al., 2003) have reported but there is lack of scientific data regarding its antiepileptic activity. Hence it was thought worthwhile to study the antiepileptic activity of Tragia involucrata in mice. 


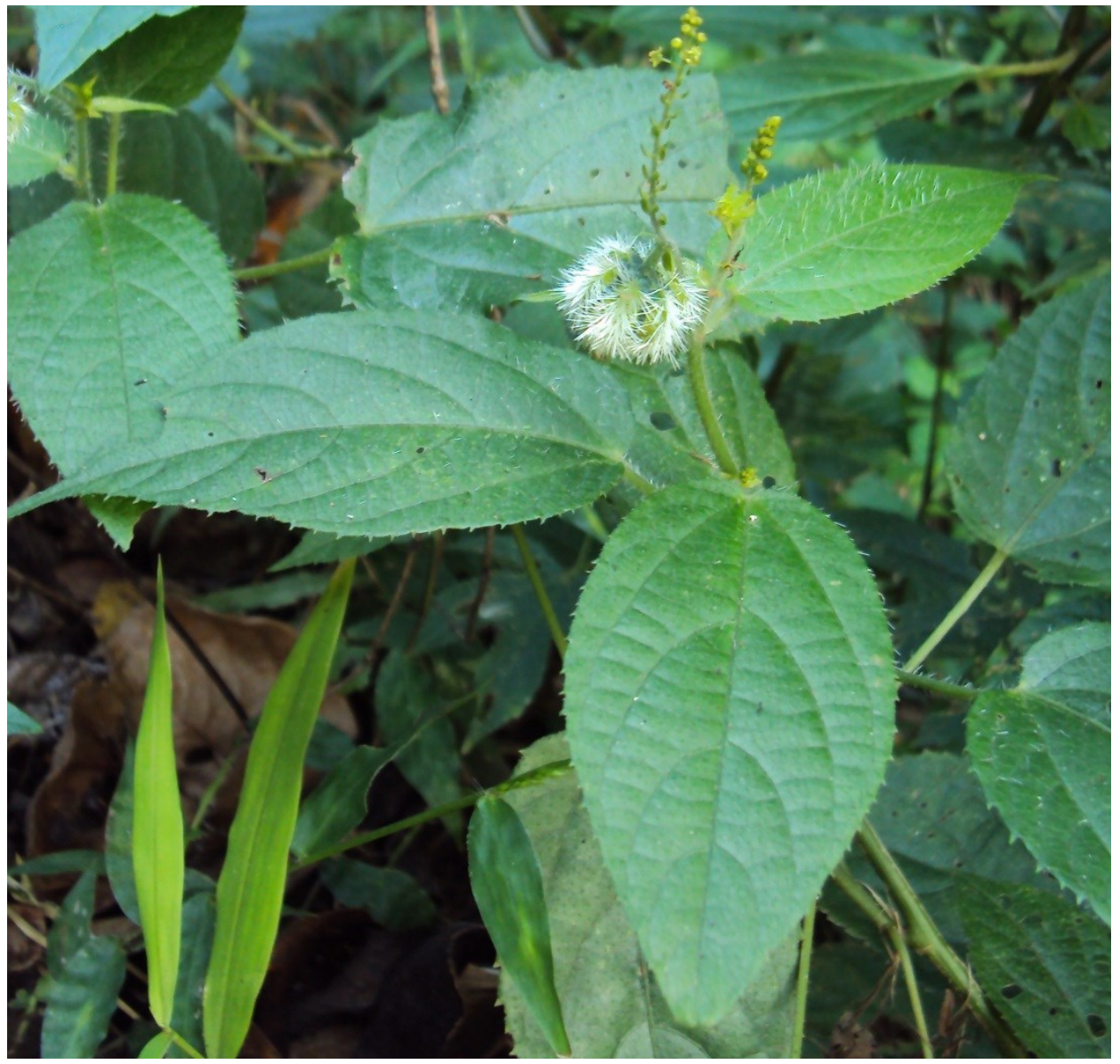

Photo 1. Tragia involucrata.

\section{MATERIALS AND METHODS}

Approval for the Project: Approval for the experiment was obtained from the Institutional animal ethics committee (IAEC), St. John's Pharmacy College, Vijayanagar, Bangalore, vide letter No. IJAHSM/IAEC/2010-02.

Plant Material: Tragia Involucrata (Family: Euphorbiaceae) was collected country side in Bhimavaram, W.G Dist, Andhra Pradesh. The plant was identified and authenticated by Dr. Shiddamallaya N, National ayurveda Dietetics Research Institute, Bangalore, India. The voucher specimen is preserved in our laboratory for future reference.

Preparation of extract: The leaves of the plant species collected were dried under shade for a period of four weeks. The dried plant material was milled to a fine powder using the commercial laboratory blender. $400 \mathrm{~g}$ dried leaves was defatted with petroleum ether for 3-4 hours at $60-80{ }^{\circ} \mathrm{C}$ then further extracted in a Soxhlet extractor with methanol for about 8-9 hours at $45^{\circ} \mathrm{C}$. Extract was collected, filtered and dried using rotary flash evaporator at 40-45 ${ }^{\circ} \mathrm{C}$ and crude residue was collected. The yield was calculated as $27 \mathrm{~g}$. The extract was stored in well closed glass container at $5{ }^{\circ} \mathrm{C}$ in refrigerator for further study. 
Preliminary Phytochemical Analysis (Trease and Evans, 1983; Khandelwal, 1996): The extracts obtained were subjected to various chemical tests to detect the chemical constituents present in them.

Animals: Healthy Swiss albino mice of either sex (18-20 gm) were procured from the Central Animal Facilities of the Drug Testing Laboratory (DTL), Bangalore. Animals were housed at our Institute's animal house facilities until they gained significant weight $(25 \pm 5 \mathrm{~g})$ suitable for the present investigation. They were housed in hygienic polypropylene cages and maintained under standard laboratory conditions for one week before the experiments started and were kept in groups of six per cage at controlled temperature $\left(22 \pm 2{ }^{\circ} \mathrm{C}\right)$ with 12 hour light/dark cycle and humidity $(50 \%)$. They received standard diet and water ad libitum. The animals were maintained in accordance with CPCSEA (Committee for the Purpose of Control and Supervision of Experimental Animals) guidelines for the care and use of laboratory animals.

Acute Toxicity study: Acute toxicity study for the methanolic extract of Tragia Involucrata Linn. was done according to the OECD guidelines No: 423 and low and high dose was selected for treatment. The methanolic extract $(70.0 \%)$ of Tragia Involucrata was administered orally in the escalating dosages, up to $2000 \mathrm{mg} / \mathrm{kg}$ to different groups of rats ( $\mathrm{n}$ $=6$, in each). The animals were observed for behavioral and physiological variations initially continuously for 4 hours, followed by $4^{\text {th }}$ hourly for 12 hours and there after once daily for 14 days. If toxic signs or lethality is not observed, then $1 / 5^{\text {th }}, 1 / 10^{\text {th }}$ and $1 / 20^{\text {th }}$ part of the limit test dose were considered as test doses for the present investigation.

\section{1. Antiepileptic Screening method}

Maximum Electro Shock (MES) induced convulsions (Pourgholami et al., 1999): The electroshock was applied via ear-clip electrodes separately to each mouse. The stimulus duration was $0.2 \mathrm{sec}$ and the current frequency 150 volts, $25 \mathrm{ohms}, 50$ pulses per second. Six mice of either sex in one group with a weight of $25 \pm 5 \mathrm{~g}$, were administered extracts for 7 days and on the experimental day, test was started 60 min after administration of extracts and $30 \mathrm{~min}$ after standard drug (phenytoin $25 \mathrm{mg} / \mathrm{kg}$ i.p.). The animals were observed for the occurrence of tonic hind limb extension and mortality for duration of 15 minute. The METI was administered to Group III and IV. Where Group I and II received $2 \%$ of Tween 80 and Phenytoin $25 \mathrm{mg} / \mathrm{kg}$ i.p. respectively, the duration of tonic hind leg extension and stupor was noted.

Pentylenetetrazole (PTZ) induced convulsion (Swinyard et al., 1952): Animals were divided into four groups. Group I received vehicles, group III and IV received extracts at different dose levels and group II was allotted for standard drug (diazepam $5 \mathrm{mg} / \mathrm{kg}$ ). All treatment and standard groups were statistically compared with vehicle groups. Vehicles, extracts are administered by oral route and standard drugs were administered by intraperitoneal (i.p.) route. Mice were administered extracts for 7 days and on the experimental day, PTZ $65 \mathrm{mg} / \mathrm{kg}$ was injected intra-peritoneal to mice $45 \mathrm{~min}$ after vehicle or extracts and 30 min after the standard drug. Immediately after PTZ administration mice were observed for (1) onset of convulsions (elapsed time from PTZ injection until convulsion occurred), (2) duration of seizure (Total time how much the animal is in convulsions) and (3) mortality for the duration of 30 minutes. 
Picrotoxin-induced convulsion (Vogel and Vogel, 2002): Picrotoxin induced convulsions are used to further evaluate CNS-active compounds. Picrotoxin is regarded as a GABA-Aantagonist modifying the function of the chloride ion channel of the GABA-A receptor complex. Animals were divided into four groups. Group I received vehicle, group III and IV received extracts at different dose levels and group II was allotted for standard drug (diazepam $10 \mathrm{mg} / \mathrm{kg}$ ). All treatment and standard groups were statistically compared with vehicle groups. Vehicles, extracts are administered by oral route and standard drugs were administered by subcutaneous (s.c) route. Mice were administered extracts for 7days and on the experimental day, PTX $3.5 \mathrm{mg} / \mathrm{kg}$ was subcutaneous injected and are observed for the following symptoms during the next $30 \mathrm{~min}$ : clonic seizures, tonic seizures, death. Times of onset of seizures and time to death are recorded.

\section{2. Biochemical estimation}

Tissue preparation: Three groups were used $(n=6)$. Group I animals (control) were administered $2 \%$ tween $80(2.0 \mathrm{ml} / \mathrm{kg}$, oral). Groups II and III animals were administered 400 and $800 \mathrm{mg} / \mathrm{kg}$ of the METI orally. One hour after administration of the extract, PTZ (65 $\mathrm{mg} / \mathrm{kg}$ ) was injected subcutaneously to all the animals in Groups I-III. On observing onset of convulsions, duration of seizure following the administration of PTZ, the animals (including control group) were sacrificed by decapitation and brain was removed, homogenized in $0.9 \%$ Nacl by using Remi motor RQT-1.2.7A.

Lipid peroxidation in brain (Ohkawa et al., 1979): Two milliliter of suspension medium was taken from $10 \%$ of tissue homogenate. To this, $2 \mathrm{ml}$ of $30 \%$ of trichloroacetic acid (TCA) was added, followed by $2 \mathrm{ml}$ of $0.8 \%$ thiobarbituric acid (TBA) reagent. The tubes were covered with aluminum foil and kept in shaking water bath for half an hour at $80{ }^{\circ} \mathrm{C}$ after half an hour; the tubes were taken out and kept in ice cold water for half an hour. There were then centrifuged at $3000 \mathrm{rpm}$ for 15 minutes. The absorbance of the supernatant was read at $535 \mathrm{~nm}$ at room temperature against appropriate blank. Blank consist of $2 \mathrm{ml}$ distilled water, $2 \mathrm{ml}$ of $30 \%$ TCA and $2 \mathrm{ml}$ of $0.8 \%$ TBA. The content of malonaldehyde (MDA), expressed as $n$ moles formed per milligram of protein in the tissue, was calculated using the formula,

\section{Concentration $=\mathrm{A} \times(\mathrm{V} / \mathrm{E}) \times \mathrm{P}$}

where, $\mathrm{A}$ is the absorbance, $\mathrm{V}$ is volume of solution, $\mathrm{E}$ is extinction coefficient $\left(1.56 \mathrm{x} 10^{5} \mathrm{~m}^{-1}\right.$ $\mathrm{cm}^{-1}$ ) and $\mathrm{P}$ is the protein content of tissue calculated as milligram of protein per gram of tissue.

Brain Glutathione (Sedlak and Lindsay, 1968): To $2 \mathrm{ml}$ of $10 \%$ of homogenate, which was prepared in sodium chloride solution, $2.5 \mathrm{ml}$ of $0.02 \mathrm{M}$ EDTA was added and shaken vigorously. To $2 \mathrm{ml}$ of this mixture $4 \mathrm{ml}$ of cold distilled water and $1 \mathrm{ml}$ of $50 \%$ trichloroacetic acid (TCA) were added and shaken for 10 minutes. Thereafter, the content were centrifuged at $3000 \mathrm{rpm}$ for 15 minute following centrifugation, $2 \mathrm{ml}$ of the supernatant was mixed with 0.4 $\mathrm{M}$ tris buffer ( $\mathrm{pH} 8.9$ ). The whole solution was mixed well and $0.1 \mathrm{ml}$ of $0.01 \mathrm{M}$ DTNB was added, the absorbance was read within 5 minutes of addition of DTNB at $412 \mathrm{~nm}$ against reagent blank with no homogenate. For blank reading, the homogenate was substituted by $2 \mathrm{ml}$ of distilled water. The amount of glutathione in tissue was expressed as $\mu \mathrm{mol} / \mathrm{g}$ of tissue. $\mu \mathrm{mol} / \mathrm{mg}$ wet tissue: 


\section{[A/13600] x dilution factor x 1000 .}

Statistical analysis: The data obtained by the various parameters was statistically evaluated by one way analysis of variance (ANOVA) followed by Dunnett test by Graph Pad Prism software (GraphPad software Inc., Version 5.0.0). The mean values \pm SEM were calculated for each parameter. Level of significance was kept at $p<0.05$.

\section{RESULTS}

Preliminary phytochemical screening: Phytochemical analysis of the methanolic extracts of Tragia involucrata revealed the presence of alkaloids, flavonoids, phenolics, phytosterol, and tannins. However, the tests show that they do not contain glycoside and fixed oil and fats.

Acute oral toxicity: Acute oral toxicity studies revealed the non-toxic nature of the METI. Methanolic extract of Tragia involucrata did not show any sign and symptoms of toxicity and mortality up to $2000 \mathrm{mg} / \mathrm{kg}$ dose.

\section{1. Antiepileptic activity}

Effect of extracts on MES-induced convulsion: The extracts caused significant decrease in the duration of THLE and in stupor period induced by maximal electroshock but was unable to completely prevent its occurrence. All the extracts showed significant protection. METI at dose of $400 \mathrm{mg} / \mathrm{kg}$ significantly $(\mathrm{p}<0.01)$ inhibited THLE in mice when compared with vehicle group. The duration of the stupor period was significantly $(p<0.001)$ decreased with dose of $800 \mathrm{mg} / \mathrm{kg}$ of METI, where as the $400 \mathrm{mg} / \mathrm{kg}$ dose of METI has decreased duration of THLE significantly $(\mathrm{p}<0.01)$. In protection against mortality standard drug diazepam and $800 \mathrm{mg} / \mathrm{kg}$ dose of METI shows high significance $(\mathrm{p}<0.001)$ with no death recorded. The $400 \mathrm{mg} / \mathrm{kg}$ dose of METI showed $16.66 \%$ where as control group showed with 4 deaths out of 6 stands with $66.66 \%$ mortality (Table 1 ).

Table 1. Effect of methanolic extract of Tragia involucrata (METI) on MES-induced convulsion in mice.

\begin{tabular}{|c|c|c|c|c|}
\hline $\begin{array}{c}\text { Experimental } \\
\text { group }\end{array}$ & $\begin{array}{c}\text { Dose in mg/kg } \\
\text { b.w }\end{array}$ & $\begin{array}{c}\text { Tonic hind limb } \\
\text { extension (THLE) } \\
\text { (sec) }\end{array}$ & Stupor (sec) & \% Mortality \\
\hline $\begin{array}{c}\text { Control } \\
(2 \% \text { tween } 80)\end{array}$ & - & $12.33 \pm 0.61$ & $197.5 \pm 5.5$ & $4 / 6(66.66 \%)$ \\
\hline $\begin{array}{c}\text { Standard } \\
\text { (Phenytoin) }\end{array}$ & 25 (i.p) & $1.16 \pm 0.30^{* * *}$ & $0.0 \pm 0.0^{* * *}$ & $0 / 6(0.0 \%)$ \\
\hline METI & 400 (p.o) & $9.16 \pm 0.70^{* *}$ & $163.6 \pm 3.17 * *$ & $1 / 6(16.66 \%)$ \\
\hline METI & 800 (p.o) & $6.83 \pm 0.30^{* * *}$ & $108.7 \pm 6.53^{* * *}$ & $0 / 6(0.0 \%)$ \\
\hline
\end{tabular}

All values expressed as Mean \pm S.E.M. ( $n=6$ in each group).

p values: $*<0.05, * *<0.01, * * *<0.001$ as compared to vehicle control (2.0\% tween 80 ) (by one-way ANOVA followed by Dunnett multiple comparison test). 
Effect of extracts on PTZ induced model: The results obtained from this model reveals that METI [Table 2] at dose of $800 \mathrm{mg} / \mathrm{kg}$ showed high significant $(\mathrm{p}<0.001)$ protection against onset of clonic convulsions induced by PTZ. The $400 \mathrm{mg} / \mathrm{kg}$ METI showed significance $(\mathrm{p}<$ 0.01). But none of the extract abolished onset of convulsions completely. On the duration of clonic convulsions the extract of $800 \mathrm{mg} / \mathrm{kg}$ dose showed high significant $(\mathrm{p}<0.001)$ protection. The METI at the dose of $400 \mathrm{mg} / \mathrm{kg}$ dose showed significant $(\mathrm{p}<0.05)$ reduction in duration of convulsions. The group pretreated with diazepam did not showed any signs of convulsions. All the animals in the diazepam group and in METI $800 \mathrm{mg} / \mathrm{kg}$ treated groups did not show any mortality, where as in METI $400 \mathrm{mg} / \mathrm{kg}$ groups showed $16.67 \%$ mortality.

Table 2. Effect of methanolic extract of Tragia involucrata (METI) on PTZ-induced convulsion in mice.

\begin{tabular}{|c|c|c|c|c|}
\hline Experimental group & $\begin{array}{c}\text { Dose } \\
\mathbf{m g} / \mathbf{k g} \text { b.w. }\end{array}$ & $\begin{array}{c}\text { Onset of clonic } \\
\text { convulsion (min.) }\end{array}$ & $\begin{array}{c}\text { Duration of } \\
\text { convulsion (min.) }\end{array}$ & $\begin{array}{c}\text { Mortality/ } \\
\text { used (\%) }\end{array}$ \\
\hline Vehicle (2 \% tween 80) & - & $1.16 \pm 0.12$ & $5.13 \pm 1.32$ & $4 / 6(66 \%)$ \\
\hline Standard (Diazepam) & 5 (i.p) & $0.00 \pm 0.00^{* * *}$ & $0.00 \pm 0.00^{* * *}$ & $0 / 6(0 \%)$ \\
\hline METI & 400 (p.o) & $3.07 \pm 0.41^{* *}$ & $2.34 \pm 0.42^{*}$ & $1 / 6(16.67 \%)$ \\
\hline METI & 800 (p.o) & $4.33 \pm 0.40^{* * *}$ & $1.11 \pm 0.14 * * *$ & $0 / 6(0 \%)$ \\
\hline
\end{tabular}

All values expressed as Mean \pm S.E.M. ( $\mathrm{n}=6$ in each group).

$p$ values: $*<0.05, * *<0.01,{ }^{* * *}<0.001$ as compared to vehicle control $(2.0 \%$ tween 80$)$ (by one-way ANOVA followed by Dunnett multiple comparison test).

Effect of extracts on PTX induced seizure model: The extract showed good protection against picrotoxin induced convulsions but unable to inhibit completely. The METI 400 $\mathrm{mg} / \mathrm{kg}$ showed less significant $(\mathrm{p}<0.05)$ value in protection on onset of clonic convulsions and in duration of convulsions also.

Table 3. Effect of methanolic extract of Tragia involucrata (METI) on PTX-induced convulsion in mice.

\begin{tabular}{|c|c|c|c|c|}
\hline Experimental group & $\begin{array}{c}\text { Dose } \\
\mathbf{m g} / \mathbf{k g ~ b . w .}\end{array}$ & $\begin{array}{c}\text { Onset of clonic } \\
\text { convulsion(min.) }\end{array}$ & $\begin{array}{c}\text { Duration of } \\
\text { convulsion(min.) }\end{array}$ & $\begin{array}{c}\text { Mortality/ } \\
\text { used (\%) }\end{array}$ \\
\hline $\begin{array}{c}\text { Vehicle } \\
(2 \% \text { tween } 80)\end{array}$ & - & $11.4 \pm 1.24$ & 4.690 .82 & $3 / 6(50 \%)$ \\
\hline Standard (Diazepam) & 5 (i.p) & $0.00 \pm 0.00^{* * *}$ & $0.00 \pm 0.00^{* * *}$ & $0 / 6(0 \%)$ \\
\hline METI & 400 (p.o) & $17.21 \pm 2.37^{*}$ & $1.94 \pm 0.27 *$ & $2 / 6(33.33 \%)$ \\
\hline METI & 800 (p.o) & $19.16 \pm 1.47^{* *}$ & $1.75 \pm 0.55^{* * *}$ & $0 / 6(0 \%)$ \\
\hline
\end{tabular}

All values expressed as Mean \pm S.E.M. ( $\mathrm{n}=6$ in each group).

$p$ values: $*<0.05, * *<0.01, * * *<0.001$ as compared to vehicle control (2.0\% tween 80$)$ (by one-way ANOVA followed by Dunnett multiple comparison test). 
The $800 \mathrm{mg} / \mathrm{kg}$ dose treated METI showed good $(\mathrm{p}<0.001)$ protection in duration of convulsions than much on its onset $(\mathrm{p}<0.01)$. METI at the dose level of $800 \mathrm{mg} / \mathrm{kg}$ showed 0 $\%$ mortality rate, whereas at dose level of $400 \mathrm{mg} / \mathrm{kg}$ showed $33.33 \%$ motility. The diazepam treated group did not show any signs of convulsions, and thus shows high significance $(\mathrm{p}<$ 0.001 ) with $0 \%$ mortality (Table 3 ).

Effects of extracts on brain lipid peroxidation: The results from brain lipid peroxidation of extract treated groups showed good significant $(p<0.001)$ inhibition of lipid peroxidation (decrease in MDA) compared to control group. The $400 \mathrm{mg} / \mathrm{kg}$ and $800 \mathrm{mg} / \mathrm{kg}$ doses of METI showed $35.67 \%$ and $38.95 \%$ decrease in MDA level in brain respectively which are significant $(\mathrm{p}<0.001)$ as compared to control (Table 4$)$.

Table 4. Effect of methanolic extract of Tragia involucrata (METI) on brain lipid peroxidation in mice.

\begin{tabular}{|c|c|c|c|}
\hline Experimental group & $\begin{array}{c}\text { Dose mg/kg } \\
\text { b.w. }\end{array}$ & $\begin{array}{c}\text { Lipid peroxidation } \\
\text { n moles of MDA/mg of } \\
\text { protein }\end{array}$ & $\begin{array}{c}\text { (\%) } \\
\text { Decreases in MDA }\end{array}$ \\
\hline $\begin{array}{c}\text { Control } \\
(2 \% \text { tween } 80)+\text { PTZ }\end{array}$ & - & $0.611 \pm 0.006$ & 0.00 \\
\hline METI + PTZ & 400 & $0.393 \pm 0.024 * * *$ & $35.67 \%$ \\
\hline METI + PTZ & 800 & $0.373 \pm 0.004 * * *$ & $38.95 \%$ \\
\hline
\end{tabular}

All values expressed as Mean \pm S.E.M. ( $\mathrm{n}=6$ in each group).

$p$ values: $*<0.05, * *<0.01,{ }^{* * *}<0.001$ as compared to vehicle control $(2.0 \%$ tween 80$)$ (by one-way ANOVA followed by Dunnett multiple comparison test).

Effects of extracts on brain Glutathione: From the results it is evident that extracts have an influence on brain glutathione level. The METI at dose level of $400 \mathrm{mg} / \mathrm{kg}$ does not showed any significant increase. In this group the glutathione level is seems to increase by $6.09 \%$. In $800 \mathrm{mg} / \mathrm{kg}$ treatment of METI extract is found to increase the level of glutathione by $23.68 \%$ which is highly significant $(\mathrm{p}<0.001)$ over control (Table 5).

Table 5. Effect of methanolic extract of Tragia involucrata (METI) on brain Glutathione level in mice.

\begin{tabular}{|c|c|c|c|}
\hline Experimental group & $\begin{array}{c}\text { Dose mg/kg } \\
\text { b.w. }\end{array}$ & $\boldsymbol{\mu}$ moles of GHS & $\begin{array}{c}\text { Increase in } \\
\text { Glutathione level } \\
\text { (\%) }\end{array}$ \\
\hline $\begin{array}{c}\text { Control }(2 \% \text { tween } 80)+ \\
\text { PTZ }\end{array}$ & - & $11.82 \pm 0.172$ & $0.00 \%$ \\
\hline METI +PTZ & 400 & $12.54 \pm 0.243$ & $6.09 \%$ \\
\hline METI + PTZ & 800 & $14.62 \pm 0.357^{* * *}$ & $23.68 \%$ \\
\hline
\end{tabular}

All values expressed as Mean \pm S.E.M. $(n=6$ in each group).

$p$ values: $*<0.05,{ }^{* *}<0.01,{ }^{* * *}<0.001$ as compared to vehicle control (2.0\% tween 80$)$ (by one-way ANOVA followed by Dunnett multiple comparison test). 


\section{DISCUSSION}

Various Phytochemicals have been reported to possess CNS activities. It is also found that many flavonoids could act as BZD- like molecules in the central nervous system (CNS) and modulate GABA-generated chloride currents in animal models of anxiety, sedation and convulsion (Raza et al., 2001). In the present investigation, the anticonvulsant activity can be attributed to the presence of alkaloids, steroids, flavonoids, tannins and saponin in aqueous and ethanolic extracts of Tragia involucrata.

A dose-related increase in anticonvulsant activity of METI suggests the presence of anticonvulsant compounds in both extracts of Tragia involucrata. THLE is the universal feature of MEST in mice, rats, rabbits, cats, monkeys and humans. Protection against THLE in MEST predicts the ability of a testing material to prevent the spread of seizure discharge from the epileptic focus in brain. In addition, effectiveness in MEST correlates with efficacy in suppressing generalized tonic-clonic and partial seizures. All the currently available AED drugs that are clinically effective in the treatment of generalised tonic-clonic seizures (phenytoin, carbamazepine, phenobarbital, VPA, lamotrigine and oxcarbazepine) are effective in the MEST. An anticonvulsant effect in the MEST model further indicates the ability of the testing material to inhibit or prevent seizure discharge within the brainstem (Vasconcelos et al., 2007). The extract at $800 \mathrm{mg} / \mathrm{kg}$ dose level showed good decrease the THLE $(\mathrm{p}<0.001)$ when compared to vehicle treated group. This indicates the presence of anticonvulsant compounds in Tragia involucrata that can be effective in suppressing MES-induced THLE and suggest that compounds in the Tragia involucrata are effective in treating generalised tonic-clonic and partial seizures. Our results demonstrate that methanolic extract of Tragia involucrate posses anticonvulsant activity. Although the convulsant mechanism of action of PTZ is poorly understood, it is reported that it is able to inhibit the chloride conductance by binding to sites of GABAA receptor complex (Park et al., 2007).

The GABA-A receptor is a member of the ligand-gated ion channel super family, GABA being the major inhibitory transmitter in the central nervous system. Binding of GABA to the GABA-A receptor activates a chloride ion flux through the channel, and ligands for the BZD binding site modulate the inhibitory effects of GABA. Such ligands of the BZD binding site are classified as positive allosteric modulators, antagonists, or negative allosteric modulators according to their spectrum of intrinsic efficacy towards the GABA-A receptor. Positive allosteric modulators increase the frequency of chloride channel openings without altering channel conductance or duration of opening.

Therapeutically, they are used as anxiolytics, anticonvulsants, sedative -hypnotics (Hema et al., 2009). Drugs that are effective against petitmal seizures reduce T- type calcium currents and these types of seizures can also be prevented by drugs that enhance GABAA BZD receptor mediated neurotransmission such as benzodiazepines and phenobarbitone (Mahomed and Ojewole, 2006). Picrotoxin, on the other hand, a GABA-A-receptor antagonist (a selective noncompetitive antagonist), produces seizures by blocking the chloride-ion channels linked to GABA-A-receptors, thus preventing the entry of chloride ions into the brain. This process will, in turn, inhibit GABA neurotransmission and activity in the brain (Olatokunboh et al., 2009), which has been widely implicated in epilepsy (Asl et al., 2007). In the present study the extracts along with diazepam shown to antagonize the seizure induced by pentylenetetrazole and picrotoxin. The extracts were also shown to delay the latency and duration of pentylenetetrazole and picrotoxin induced seizures, suggesting that the extracts exhibiting anticonvulsant affect when compared to the vehicle group, probably by opening the chloride channels associated with GABA receptors. 
Free radicals have been suggested to be most likely candidate responsible for producing the neuronal changes mediating the behavioral deficits in neurodegeneration disorders. Number of studies has demonstrated that antioxidants are effective in the rodent models of epilepsy (Debnath et al., 2010). Oxygen is necessary for many important aerobic cellular reactions but it may undergo electron transfer reactions which generate highly reactive oxygen free radicals such as superoxide anion radical, hydrogen peroxide or the hydroxyl radical. The brain is extremely susceptible to oxidative damage induced by these reactive species (Kumar and Gandhimathi, 2010).

The brain and nervous system are particularly prone to the free radical damage, since the membrane lipids are very rich in polyunsaturated fatty acids and areas of human brain are very rich in iron, which plays an essential role in generating free radicals. As free radicals are potentially toxic, they are usually inactivated or scavenged by antioxidants before they can inflict damage to lipids, proteins or nucleic acids (Surapaneni, 2007). Lipid peroxidation is well established mechanism of cellular in both animals and plants, and is used as an indicator of oxidative stress in cells and tissues. The estimation of peroxidation of lipids has been carried out by number of methods of which TBA reactive substances is selected because of its high sensitivity simplicity in operation (Debnath et al., 2010). MDA is an end product of lipid peroxidation, a measure of free radical generation. Glutathione is the most abundant intracellular thiol and low molecular weight tripeptide found in living cells. It reacts with the free radicals and can protect cells from singlet oxygen, hydroxyl radical and superoxide radical damage (Gupta et al., 2009). Prolonged depletion of GSH in the brain is associated with oxidative neuronal death (Varija et al., 2009).

In our study the methanolic extracts of Tragia involucrata showed significant decarese in MDA level in the lipid peroxidation profile of the extract treated groups when compared to vehicle treated group. The extract was also showed a significant $(p<0.001)$ increase in the brain glutathione levels in both extracts at $800 \mathrm{mg} / \mathrm{kg}$ dose when compared to vehicle treated group proving the antioxidant property.

The majority of currently available antiepileptic drugs fall into one of two pharmacological classes, those that modulate neuronal voltage-gated sodium channels (e.g. carbamazepine, phenytoin, lamotrigine, and topiramate) and those that modulate inhibitory GABAergic neurotransmission (e.g. benzodiazepine, vigabatrin and tiagabine). While, small number of AEDs such as ethosuximide, gabapentin and possibly levetiracetam, may exert their effects via an interaction with voltage-operated calcium channels. The ability of the extract to exhibit activity against these two types of seizures suggests that it may act through different mechanisms to elicit its anticonvulsant effects, such as voltage-gated sodium, calcium, and potassium or GABAergic pathway (Yaua et al., 2008). The way how Tragia involucrata reduced the onset of convulsions and protection provided against MES, PTZ and PTX it suggest that the extract contain substances like alkaloids, flavonoids, tannins and phenolics content of the plant extract may interact with the BZD site in the GABA-A-BZD receptor complex and may be with ion channels. Along with its antioxidant property, which really have to be seen through it.

\section{CONCLUSION}

The methanolic leaf extract of Tragia involucrate Linn. has demonstrated potential antiepileptic properties and safe in the experimental animals at the doses used. However, further studies still needed to be carried on exposure of the extract to humans, and its use in 
folk medicine for seizure control should be accompanied by regular assessment of level of consciousness and blood pressure.

\section{References}

[1] Asl, M.A., S.S. Rad, and F. Zamansoltani, 2007. Anticonvulsant effects of aerial parts of passiflora incarnata extract in mice: involvement of benzodiazepine and opioid receptors. BMC. Complement. Altern. Med., 7: 1-6.

[2] Ayyanar, M. And S. Ignacimuthu, 2005. Traditional knowledge of Kani tribals in Kouthalai of Tirunelveli hills, Tamil Nadu, India. J. Ethnopharmacol., 102: 246-255.

[3] Debnath, S., M. Kannadasan, A. Acharjee, C, Bhattacharjee, S. Kumar, and G.G. Kumar, 2010. Antioxidant activity of the hydro-alcoholic extract of Erythrina fusca Lour. bark against the animal models of epilepsy. J. Chem. Pharm. Res., 2: 379-383.

[4] Dhara, A.K., V. Suba, T. Sen, S. Pal, and A.K. Chaudhary, 2000. Preliminary studies on anti inflammataoray and analgesic activity of the methanolic fraction of root extract of Tragia involucrata Linn. J. Ethanopharmacol., 72: 265-268.

[5] Dhara, A.K., S. Pal, and A.K. Chaudhary, 2002. Psychopharmacological Studies on Tragia involucrata Root Extract. Phtother. Res. 16: 326-330.

[6] Ezekiel, I., M.A. Mabrouk, J.O. Ayo, A.D. Goji, A.O. Okpanachi, A. Mohammed, and Y. Tanko, 2010. Study of the Effect of Hydro-Ethanolic Extract of Commiphora Africana (Stem-bark) on Sleeping Time and Convulsion in Mice. Asian. J. Med. Sci., 2: 85-88.

[7] Gupta, Y.K., S. Briyal, and M. Sharma, 2009. Protective effect of curcumin against kainic acid induced seizures and oxidative stress in rats. Ind. J. Physiol. Pharmacol., 53: $39-46$.

[8] Hema, B., S. Bhupendra, T.S. Mohamed Saleem, and K. Gauthaman, 2009. Anticonvulsant Effect of Drosera burmannii Vahl. Int. J. Applied. Res. Nat. Prod., 2: 14.

[9] Joy, P.P., J. Thomas, S. Mathew, and B.P. Skaria, 2001. Medicinal Plants Tropical Horticulture. Vol. 2., Calcutta: Naya Prokashan.

[10] Kar, A., B.K. Choudhary, and N.G. Bandyopadhyay, 2003. Comparative evaluation of hypoglycaemic activity of some Indian medicinal plants in alloxan diabetic rats. $J$ Ethnopharmacol., 84: 105-108.

[11] Khandelwal, K.R., 1996. Practical pharmacognosy techniques and experiments. 3rd ed. Pune: Nirali Prakashan.

[12] Kirtikar, K.R. and B. D. Basu, 1977. Indian medicinal plants. $2^{\text {nd }}$ ed, Vol. 1., Dehradun: International Book Publishers.

[13] Kumar, A.S. and R. Gandhimathi, 2010. Effect of Guettarda speciosa extracts on antioxidant enzymes levels in rat brain after induction of seizures by MES and PTZ. $J$. Nat. Prod., 3: 80-85.

[14] Mac, T.L., D.S. Tran, F. Quet, P. Odermatt, P.M. Preux, and C.T. Tan, 2007. Epidemiology, aetiology, and clinical management of epilepsy in Asia: a systematic review. Lancet. Neurol., 6: 533-543. 
[15] Mahomed, I.M. and J.A. Ojewole, 2006. Anticonvulsant activity of Harpagophytum procumbens DC (Pedaliaceae) secondary root aqueous extract in mice. Brain. Res. Bull., 69: 57-62.

[16] Medappa, N., 2001. Developments In Mental Health Scenario: Need To Stop Exclusion - Dare To Care. ICMR Bulletin; 2001; New Delhi. Indian Council of Medical Research.

[17] Ohkawa, H., N. Ohishi, and K. Yagi, 1979. Assay for lipid peroxides in animal tissues by thiobarbituric acid reaction. Anal. Biochem., 95: 351-358.

[18] Olatokunboh, A.O., Y.O. Kayode, and O.K. Adeola, 2009. Anticonvulsant activity of Rauvolfia Vomitoria (Afzel). Afric. J. Pharm. Pharmacol., 3: 319-322.

[19] Palani, S., S. Nirmal Kumar, R. Gokulan, D. Rajalingam, and B. Senthil Kumar, 2009. Evaluation of Nephroprotective and antioxidant potential of Tragia involucrate. Drug Invention Today., 1: 55-60.

[20] Park, H.G., S.Y. Yoon, J.Y. Choi, G.S. Lee, J.H. Choi, C.Y. Shin, 2007. Anticonvulsant effect of wogonin isolated from Scutellaria baicalensis. Eur. J. Pharmacol., 574: 112119.

[21] Pourgholami, M.H., S. Majzoob, M. Javadi, M. Kamalinejad, G.H. Fanaee, and M. Sayyah, 1999. The fruit essential oil of Pimpinella anisum exerts anticonvulsant effects in mice. J. Ethnopharmacol., 66: 211-215.

[22] Rahmatullah, M., A.T. Kabir, M. Rahman, S. Hossan, Z. Khatun, A. Khatun, 2010. Ethnomedicinal Practices among a Minority Group of Christians Residing in Mirzapur Village of Dinajpur District, Bangladesh. Adv. In. Nat. Appl. Sci., 4: 25-51.

[23] Raza, M., F. Shaheen, M.I. Choudhary, S. Sombati, 2001. Anticonvulsant activities of ethanolic extract and aqueous fraction isolated from Delphinium denudatum. J. Ethnopharmacol., 78: 73-78.

[24] Rout, S.K. and D.M. Kar, 2010. A review on antiepileptic agents, current research and future prospectus on conventional and traditional drugs. Int. J. Pharm. Sci. Rev. Res., 3: $19-23$.

[25] Samy, R.P., P. Gopalakrishnakone, M. Sarumathi, and S. Ignacimuthu, 2006. Wound healing potential of Tragia involucrata extract in rats. Fitotherapia., 77: 300-302.

[26] Samy, R.P., S. Ignacimuthu, and A. Sen, 1998. Screening of 34 Indian medicinal plants for antibacterial properties. J Ethnopharmacol., 62: 173-182.

[27] Sarada, S., G.S. Nair, and B.R. Reghunath, 2002. Quantification of medicinally valuable weeds in oil palm plantations of Kerala. J. Trop. Agric., 40: 19-26.

[28] Savithramma, N., Sulochana, K.N. Rao. 2007. Ethnobotanical survey of plants used to treat asthma in Andhra Pradesh, India. J Ethnopharmacol., 113: 54-61.

[29] Sedlak, J., R.H. Lindsay, 1968. Estimation of total protein bound and non protein bond sulphydryl group in tissue with Ellman's reagent. Anal. Biochem., 25: 192-197.

[30] Silja, V.P., K.S. Varma, and K.V. Mohanan, 2008. Ethanomedical plant knwoledge of the Mullu kuruma tribe of Wayanad district, Kerala. Ind. J. Trad. Knowl., 7: 604-612.

[31] Surapaneni, K.M., 2007. Status of Lipid Peroxidation, Glutathione, Ascorbic Acid, Vitamin E and Antioxidant Enzymes in Schizophrenic Patients. J. Clin. Diag. Res., 1: $39-44$. 
[32] Swinyard, E.A., W.C. Brown, and L.S. Goodman, 1952. Comparative assays of antiepileptic drugs in mice and rats. J. Pharmacol. Exp. Ther., 106: 319-330.

[33] Trease, G.E. and M.C. Evans, 1983. Text book of Pharmacognosy. London: Bailliare Tindall. 12: pp: 193.

[34] Udayan, P.S., M.K. Harinarayanan, K.V. Tushar, and I. Balachandran, 2008. Some common used by Kurichiar tribes of Tirnelli forest, Wayanad district, Kerala in medicine and other traditional uses. Ind. J. Trad. Knowl., 7: 250-255.

[35] Varija, D., K.P. Kumar, K.P. Reddy, and V.K. Reddy, 2009. Prolonged constriction of sciatic nerve affecting oxidative stressors \& antioxidant enzymes in rat. Ind. J. Med. Res., 129: 587-592.

[36] Vasconcelos, S.M., N.M. Lima, G.T. Sales, G.M. Cunha, L.M. Aguiar, E.R. Silveira, 2007. Anticonvulsant activity of hydroalcoholic extracts from Erythrina velutina and Erythrina mulungu. J. Ethnopharmacol., 110: 271-274.

[37] Vogel, H. Gerhard, H. Vogel Wolf gang, 2002. (Eds) Drug discovery and Evaluation pharmacological assays (Springer). 2: (E) 424.

[38] Wannang, N.N., J.A. Anuka, H.O. Kwanashie, S.S. Gyang, and A. Auta, 2008. Antiseizure activity of the aqueous leaf extract of Solanum nigrum linn (solanaceae) in experimental animal. Afr. Health. Sci., 8: 74-79.

[39] Yaua, J., A.H. Yaro, M.S. Abubakarb, J.A. Anukaa, and I.M. Hussainia, 2008. Anticonvulsant activity of Carissa edulis (Vahl) (Apocynaceae) root bark extract. $J$. Ethnopharmacol., 120: 255-258. 